Bulgarian Academy of Sciences. Space Research and Technology Institute. Aerospace Research in Bulgaria. 30, 2018, Sofia

DOI: https://doi.org/10.3897/arb.v30.e08

\title{
SCALES FOR MEASURING UAV MICRO-MOTOR STATIC THRUST
}

\author{
Svetoslav Zabunov, Garo Mardirossian \\ Space Research and Technology Institute - Bulgarian Academy of Sciences
}

\begin{abstract}
With the advent of micro-sized unmanned helicopters and airplanes weighing under $250 \mathrm{~g}$ certain needs for measurement instruments and setups are emerging. The authors have identified the lack of micro-motor measurement instruments and more specifically a static thrust gauge device. For this reason, a scales to measure static motor thrust was advised and further developed as a laboratory setup.

The motors that are subject to testing with the described instrument are the brushed microsized coreless electric motors, well suited for micro-drones with total weight under $250 \mathrm{~g}$. The scale is fitting different sizes of micro-motors and appropriate control of the input voltage is provided. The instrument is measuring simultaneously the applied voltage to the motor and the current it consumes, along with the static thrust the motor generates. The scale is versatile - it measures both pusher and tractor propeller configurations. Pusher propellers in micro-drones are gaining significant attention lately due to their better efficiency characteristics.
\end{abstract}

\section{Introduction}

The miniaturization of unmanned aerial vehicle avionics in the last few years has led to increased interest in the design of drones having maximum total weight less than or equal to $250 \mathrm{~g}$ [1]. Further, in the legislation of several countries, a registration requirement was recently introduced, applying to drones, as well as drone owners of machines weighing over $250 \mathrm{~g}$.

There is a long list of benefits the micro-UAVs offer in comparison to larger drones. Most important of these are:

- Low cost for manufacturing and maintenance.

- Lower risk for damaging objects and living beings due to less weight and decreased kinetic energy of the rotors.

- Ease of transportation and storage.

- Low visibility due to small dimensions.

- Reduced RADAR signature [2-6].

- Reduced acoustic signature.

- Negotiability through windows and manoeuvrability inside buildings. 
The current paper discloses a test instrument, developed by the authors, used to measure the static thrust generated by coreless brushed micro-motors, suitable for micro-drones. The test setup is shown in Fig. 1. The proposed device is a weighing scale with three arms and is designed to be implemented in examining micro-motors having $7 \mathrm{~mm}$ diameter of the motor body. There are different motor sizes according to motor body length: $17 \mathrm{~mm}, 20 \mathrm{~mm}$, etc. Motors with different body diameter are also suitable to be tested with the proposed equipment after minor modifications.

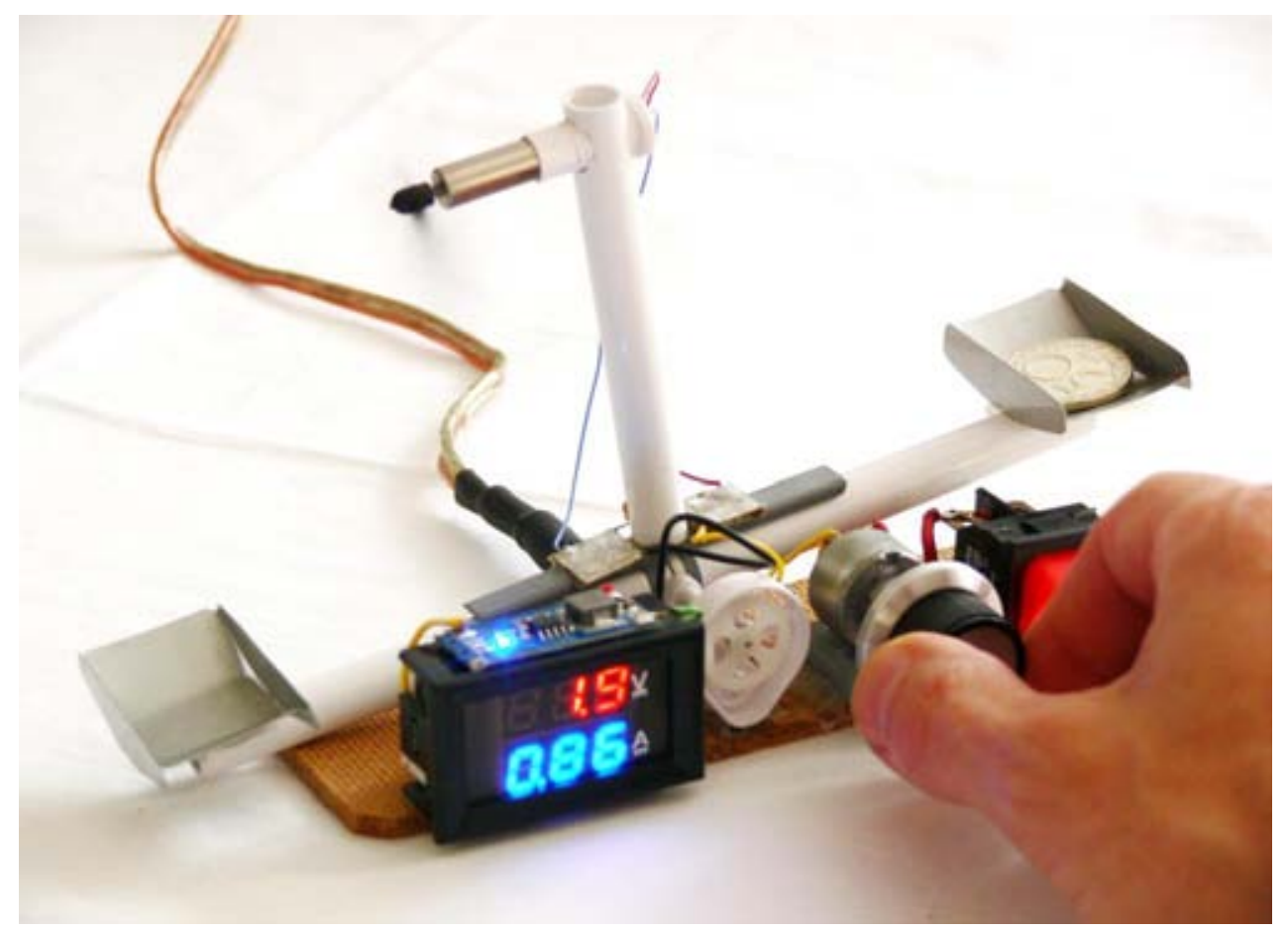

Fig. 1. Scale for measuring static thrust of micro-motors

Fig. 2 presents some of the most frequently used coreless micro-motors for small UAVs. All of the motors up to $8.5 \times 20 \mathrm{~mm}$ are powered with maximum supply voltage of $3 \mathrm{~V}$. The motor mounted on the scales in Fig. 1 is a $7 \times 20 \mathrm{~mm}$ type motor (Fig. 2 - left). 


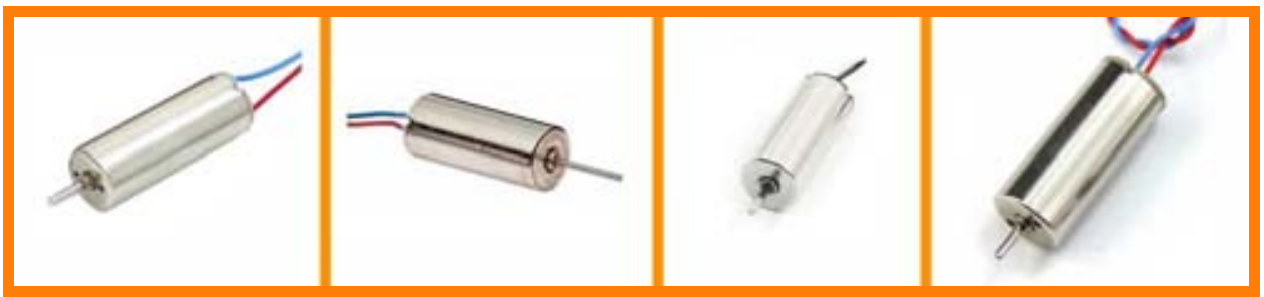

Fig. 2. Brushed coreless micro-motors, frequently employed in micro-UAVs.

From left to right: $7 \times 20 \mathrm{~mm}, 7 \times 16 \mathrm{~mm}, 6 \times 14 \mathrm{~mm}, 8.5 \times 20 \mathrm{~mm}$.

\section{Construction}

The construction of the scales is based on the balanced scales principle the scales arms have equal length, pivoted on a fulcrum. Nevertheless, unlike the classic balance scales, the instrument proposed here has three, instead of two arms with equal length. The arms are positioned in one plane and are at 90 degree angles from one another.

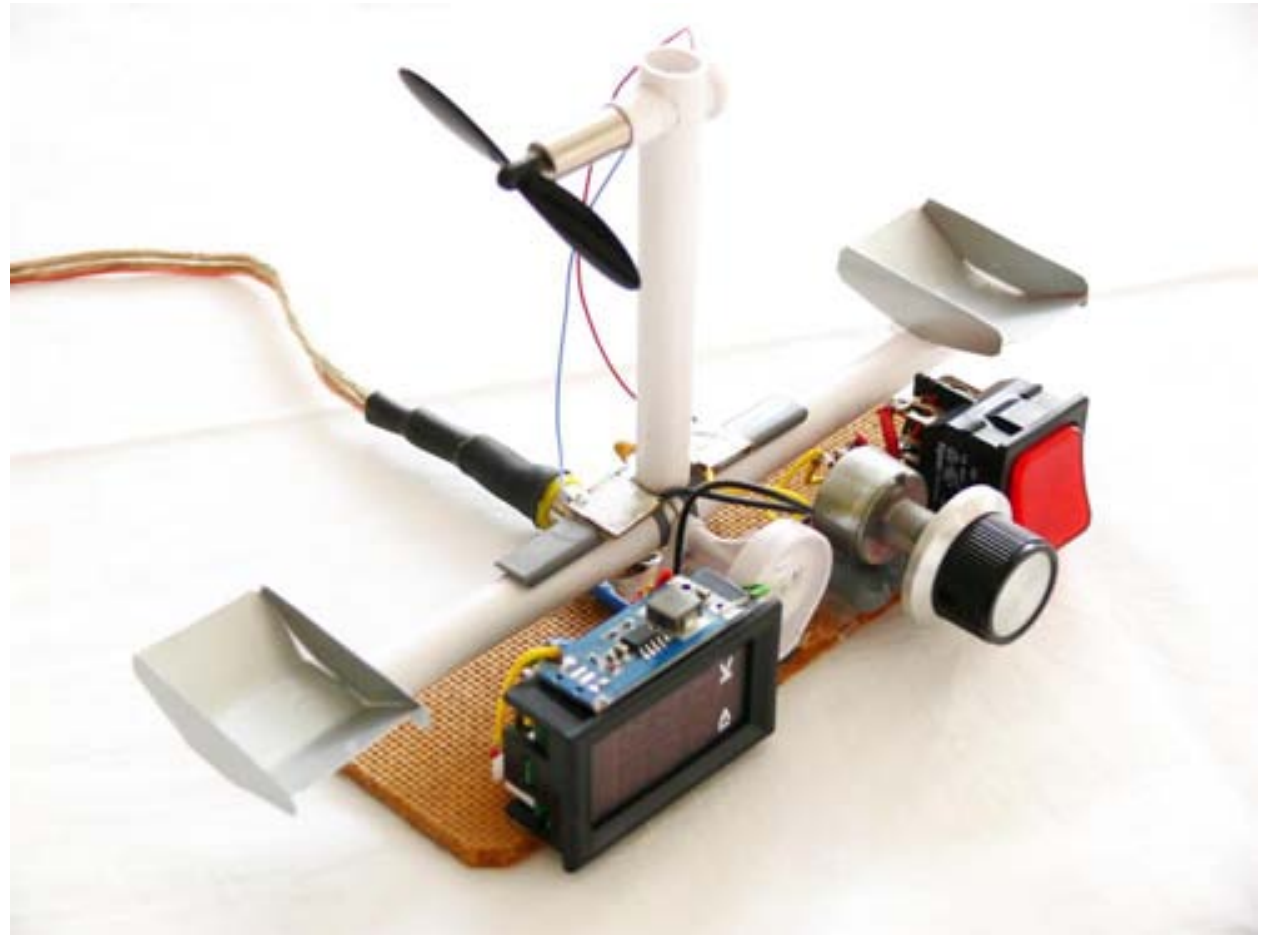

Fig. 3. Static thrust scales in equilibrium 
Applying the same moment of force, but with inverse signs, to two of the arms would keep the scales in equilibrium. Due to arms' equal length, in order to generate equal moments of force one should apply equal forces to arms' ends, such that each force is perpendicular to the given arm and lies in the plane, defined by the three arms.

The moving part - the arms structure - is secured to the scales base through a bearing, acting as the scales fulcrum. The friction of the bearing introduces an error of less than $0.1 \mathrm{~g}$.

The instrument in balance is shown in Fig. 3. Two of the arms are horizontal and have weighing dishes where weights may be placed. The third arm is vertical and employs a motor mount.

\section{Electrical schematic}

The scales instrument has a socket for supplying electrical power through a cable. The voltage delivered to the device is $3.6 \mathrm{~V}$, coming from a single cell Li-Ion battery. The motor voltage is filtered by a $100 \mathrm{nF}$ capacitor. Further, the voltage is manually regulated by means of a powerful $(2 \mathrm{~W}) 10 \mathrm{ohm}$ potentiometer, connected in series with the motor.

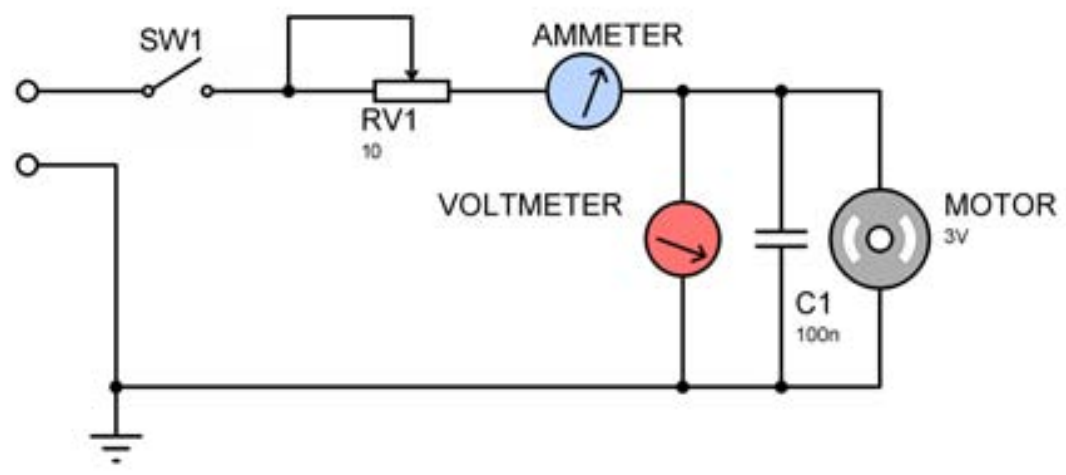

Fig. 4. Scales electrical schematic

A digital voltmeter measures the voltage applied to the motor and displays the result in volts on a red coloured LED digital display (Fig. 1, 4 and 6). The current flowing through the motor is measured by a digital ammeter, displaying the current in amperes on a blue coloured LED digital display (Fig. 1, 4 and 6). Both metering instruments were laboratory calibrated. The electrical circuit is powered on and off using a master switch (the red coloured switch on the right-hand side of the scales - Fig. 1). 


\section{Measurements}

In Fig. 3 and 6, the motor mount was populated with a $7 \times 20 \mathrm{~mm}$ coreless brushed motor having shaft diameter of $0.9 \mathrm{~mm}$. On the shaft, a $55 \mathrm{~mm}$ tractor propeller was mounted (black coloured propeller). This propeller is standard for the attached motor and generally delivers maximum static thrust in the range of 20-22 g. A common rule for multi-rotor helicopters is to fly at $50 \%$ of the maximum static thrust a rotor is capable of generating. For this reason the given motor has been tested at $10 \mathrm{~g}$ static thrust.

For a weight of $10 \mathrm{~g}$ two coins of 50 Bulgarian Lev cents (see Fig. 5) were adapted. According to Bulgarian National Bank, each such coin weighs $5 \mathrm{~g}$.

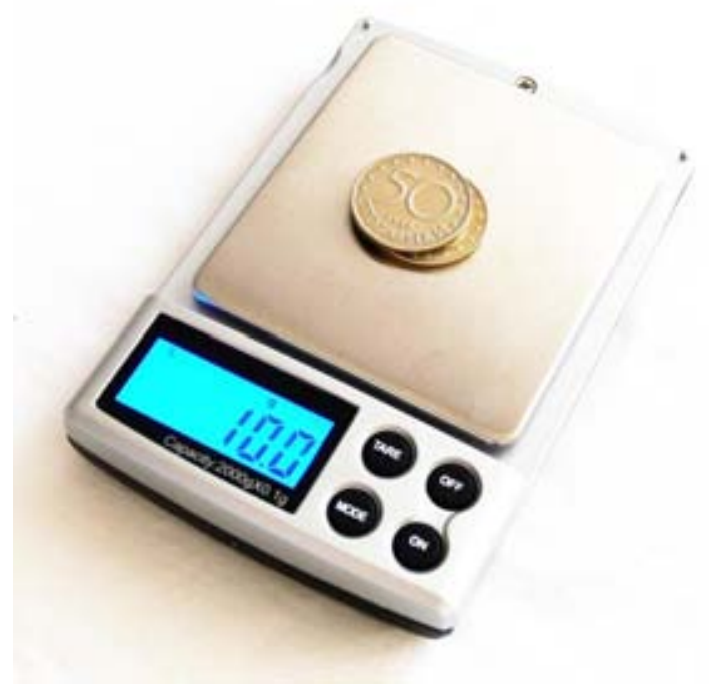

Fig. 5. Used scales weight of $10 \mathrm{~g}$

The process of searching for equilibrium starts by placing the $10 \mathrm{~g}$ weight in the right-hand side scales dish (Fig. 6 - left), turning the potentiometer to minimum voltage and switching on the master switch. The pot is then slowly turned such that voltage is increased. The motor is measured to generate $10 \mathrm{~g}$ of thrust when the scales has just left balance - but instead of inclining to the side of the weight, it falls to the other side - left inclination - lifting the $10 \mathrm{~g}$ weight up. 


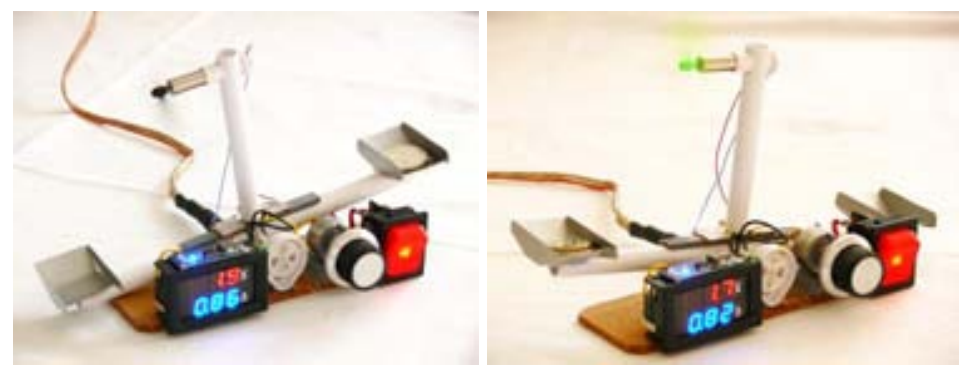

Fig. 6. Tractor versus pusher propeller configuration

The same measurement is taken after mounting a pusher propeller (green coloured propeller) of the same type to the motor shaft (Fig. 6 - right). Now, the weight is moved to the left weighing dish and the process of searching balance is repeated.

The results of the measurements show a definite benefit from using a pusher instead of a tractor propeller. The measurement results are summarized in Table 1. A $14.7 \%$ savings in power drain is observed, which translates directly into the same increase in fight time and range of the unmanned aerial vehicle. On the other hand, this power economy may be used to increase the payload of the UAV.

The decrease of power consumed for creating the needed static thrust comes from the lack of aerodynamic drag (form drag and skin friction) against the beam, holding the rotor - in this case this is the scales arm - and the motor body. In real scenario, a pusher propeller's accelerated airflow will avoid any parts of the aircraft it might encounter, which would, otherwise generate unwanted parasitic drag.

Table 1. Generating $10 \mathrm{~g}$ static thrust in tractor and pusher propeller configurations

\begin{tabular}{|l|l|l|l|l|}
\hline & Voltage & Current & Power & Thrust efficiency \\
\hline Tractor propeller configuration & $1.9 \mathrm{~V}$ & $0.86 \mathrm{~A}$ & $1.634 \mathrm{~W}$ & $6.12 \mathrm{~g} / \mathrm{W}$ \\
\hline Pusher propeller configuration & $1.7 \mathrm{~V}$ & $0.82 \mathrm{~A}$ & $1.394 \mathrm{~W}$ & $7.17 \mathrm{~g} / \mathrm{W}$ \\
\hline Power gain: $14.7 \%$
\end{tabular}

\section{Conclusions}

The authors have been in development of unmanned aerial vehicle models since 2014 and have intentions in future continuation of their work [7]. The advent of micro UAVs as a branch of unmanned vehicles is posing significant challenge, but also giving pleasant rewards for the large area of their possible implementation. 


\section{References}

1. Coffey, T., J.A. Montgomery. The Emergence of Mini UAVs for Military Applications. Defense Horizons Dec. 2002, 22, 1-8.

2. Chenchen, J. Li, H. Ling. Radar Signatures of Small Consumer Drones. AP-S/USNC-URSI IEEE, Puerto Rico, 2016, 1-23.

3. Hammer, M., M. Hebel, B. Borgmann, M. Laurenzis, M. Arens. Potential of LIDAR sensors for the detection of UAVs. Proc. SPIE 10636, Laser Radar Technology and Applications XXIII, 1063605 (10 May 2018); DOI:10.1117/12.2303949.

4. Molchanov, P., R. I.A. Harmanny, J. J.M. de Wit, K. Egiazarian, and J. Astola. Classification of small UAVs and birds by micro-Doppler signatures. Int. J. of Microwave and Wireless Techno., 2014, 6, 3/4, 435-44. Cambridge University Press and the European Microwave Association, 2014, DOI:10.1017/S1759078714000282.

5. Kim, B.-K., J. Park, S.-J. Park et al. Drone Detection with Chirp-Pulse Radar Based on Target Fluctuation Models. ETRI Journal, 2018, 40, 2, 188-96.

6. Birch, G.C., J.C. Griffin, and M.K. Erdman. UAS Detection, Classification, and Neutralization: Market Survey 2015. Sandia Report, SAND2015-6365, 1-74.

7. Zabunov, S., P. Getsov, and G. Mardirossian. XZ-4 vertical takeoff and landing multi-rotor aircraft. Asian Journal of Natural \& Applied Sciences, 2014, 3, 4, 1-7.

\section{ВЕЗНИ ЗА ИЗМЕРВАНЕ НА СТАТИЧНАТА ТЯГА НА МИКРОДВИГАТЕЛИ ЗА БЛА}

\section{С. Забунов, Г. Мардиросян}

\section{Резюме}

С навлизането на безпилотните летателни апарати (БЛА) с микроразмери и маса не повече от $250 \mathrm{~g}$, се появява и нужда от измервателни средства, адаптирани към тези машини. Тук е констатирана липса на подобни средства и по-конкретно везни за измерване на статичната тяга, генерирана от двигателите. Поради това е разработена лабораторна везна с гореописаното предназначение. Могат да се тестват колекторни двигатели без сърцевина в ротора.

Двигателите, които са предмет на измервания и тестване с описания инструмент, са с миниатюрни размери. Последните са подходящи за приложение в БЛА с микро-размери и маса до $250 \mathrm{~g}$.

Везната работи с различни размери на двигателите и предоставя контрол на захранващото им напрежение, тока на консумация и статичната тяга. Тя е приложима за измерване, както на теглещи, така и на тласкащи витла. Тласкащите витла за микро-дронове придобиват все по-голяма популярност поради по-високата си ефективност. 